\title{
İngilizce Öğrenmeye Yönelik Motivasyon Ölçeği: Geçerlik ve Güvenirlik Çalışması
}

\author{
A Motivation Scale Intended for Learning English: A Validity and Reliability \\ Study
}

\author{
Beylü KARAYAZGAN , Öğr. Gör., Ege Üniversitesi Yabancı Diller Yüksekokulu, İzmir, beylu81@gmail.com, ORCID \\ ID:https://orcid.org/0000-0002-5088-4508
}

\begin{abstract}
Asuman Seda SARACALOĞLU , Prof. Dr., Adnan Menderes Üniversitesi Eğitim Programları ve Öğretim Anabilim Dalı, Aydın, sedasaracal@gmail.com, ORCID ID: https://orcid.org/0000-0001-7980-0892
\end{abstract}

Karayazgan, B. ve Saracaloğlu, A.S. (2021). İngilizce öğrenmeye yönelik motivasyon ölçeği: Geçerlik ve güvenirlik çalışması. Batı Anadolu Eğitim Bilimleri Dergisi, 12 (1), 321-332.

Öz. Eğitimin temel faktörlerinden biri olan motivasyon, öğrencilerin özellikle yabancı dil eğitimi gibi edinimi zor olan derslerde önem ve öncelik verilmesi gereken boyutlardan biridir. Bu sebeple, bu çalışmada amaç, üniversite hazırlık sınıfı öğrencilerinin İngilizce öğrenmeye yönelik motivasyon düzeylerini tespit etmek için Likert-tipi bir ölçme aracı geliştirmektir. Bu amaç doğrultusunda, alanyazın taramasından yola çıkarak bir ön-test oluşturularak uzmanların değerlendirilmesi istenmiştir. Verilen öneriler ışığında gereken değişiklikler yapılmış; ardından, ölçeğin güncellenmesi için 554 üniversite İngilizce hazırlık sınıfı öğrencisi ile ilk uygulama yapılmıştır. Ölçeğin geçerlik çalışmaları için açımlayıcı faktör analizi yapıımıştır. Ölçeğin Cronbach- $\alpha$ güvenirlik katsayısı ise 0.91 olarak bulunmuştur. Elde edilen faktör analizi sonuçlarında, ölçme aracının toplam varyansın \%40’ını açıklayan iki faktörü içerdiği ortaya çıkmıştır. Ölçek, üzerinde yapılan değişikliklerden sonra 545 üniversite İngilizce hazırlık sınıfı öğrencisine uygulanmış, geçerliği belirlemek amacıyla doğrulayıcı faktör analizi yapılmıştır. Geliştirilen ölçme aracının güvenirliğiyle ilgili Cronbach alfa katsayıları, içsel motivasyon boyutu için 0.94, dışsal motivasyon boyutu için ise 0.97 olarak bulunmuştur. Doğrulayıcı faktör analizi sonucunda uyum indekslerine bakıldığında ki kare değeri serbestlik derecesine bölündüğünde 4.53 değeri bulunmuştur. Böylelikle, 32 maddeden oluşan geçerli ve güvenilir bir ölçek elde edilmiştir.

Anahtar Kelimeler: İngiliz dili eğitimi, İngilizce öğrenme, Motivasyon ölçeği.

\begin{abstract}
Motivation, one of the basic factors of education, is a dimension which should not be neglected in the courses especially students who have difficulty in foreign language learning. Thus, the aim of this study is to develop a likert scale to determine university students' motivation levels intended for learning English. For this, a pre-test was formed with regard to literature review and was presented to experts' evaluation. After the changes related to the experts' suggestions, first implementation was conducted with 554 university English preparatory class students to update the scale. Exploratory factor analysis was applied to determine the validity of the scale. Scale's Cronbach alfa reliability coefficient was found as 0.91 . The results of the factor analysis showed that the scale has two factors which show $40 \%$ of the total variance. After the changes, the scale was applied to 545 university English preparatory class students and confirmatory factor analysis was done to determine validity. Scale's Cronbach alfa coefficient related to reliability was found as 0.94 for 'intrinsic motivation' dimension and 0.97 for 'extrinsic motivation' dimension. When the fit indexes, which were obtained from the confirmatory factor analysis, were investigated and chi square value was divided to degrees of freedom, the value was found as 4.53. By this way, a valid and reliable scale, which includes 32 items, was developed.
\end{abstract}

Keywords: English language teaching, learning english, Motivation scale. 


\section{Extended Abstract}

Introduction. Nowadays, it is clear that foreign language education is gaining more importance day by day, and many people spend a lot of money and time to learn a foreign language. However, students' opinions or inadequacies about learning English can be a factor which prevents them from reaching the desired level. For this reason, determining the motivation of students for learning a foreign language and preparing programs accordingly may affect the language learning and teaching process positively. The aim of this study is to develop a reliable and valid Likert-type measurement tool that measures the motivation of university prep students to learn English. For this aim, in the first application, the scale was implemented to all English preparatory class students studying at Ege University School of Foreign Languages in Izmir in the spring semester. In the second application, it was implemented to all English preparatory students studying at Yaşar University School of Foreign Languages in Izmir in the summer school.

Method. The sample of the study consisted of 554 students at Ege University and 545 students at Yaşar University. The answer choices for the items in the scale were arranged as "Strongly Agree", "Agree", "Partially Agree", "Disagree" and "Strongly Disagree". The drafted scale was examined by 9 instructors who are professionals in English language teaching. Before the expert opinion, the 2-dimensional scale consisted of 52 items in the form of intrinsic motivation and extrinsic motivation. It was arranged as 53 items after it. The expressions were evaluated on the basis of clarity, fluency, appropriate use of language, writing motivational statements and comprehensibility. The ones with language and clarity problems were corrected according to the recommendations. After this rearrangement, the scale was applied to 554 students by simple random sampling method in order to determine the construct validity and reliability coefficient values. As a consequence of the exploratory factor analysis, it was seen that some items did not work as desired and they were excluded from the scale. After this process, EFA was performed again and the scale took its final form with 32 items.

As a result of the first analysis, items that did not include any dimensions and those that did not work in the expected direction were removed from the scale. Each item was removed one by one and the analysis was repeated. The items $10,11,13,14,15,16,17,21$, and 22 , in total, 9 items in the intrinsic motivation sub-dimension were removed. For the extrinsic motivation sub-dimension, a total of 12 items were removed, with items $1,2,3,4,5,6,7,8,11,18,19$, and 21.

The trial form of the measurement tool, which was arranged according to expert opinions and pre-application results, indicates the construct validity of the scale. Therefore, it was applied to a group of 545 students with simple random sampling method in order to determine the sub-dimensions and to determine the level of reliability. The data were analyzed using SPSS 23.0 package program. After the confirmatory factor analysis, the scale was finalized without the need for item extraction.

Results. Cronbach- $\alpha$ reliability coefficients for the sub-dimensions of the scale were calculated as 0.93 for the intrinsic motivation sub-dimension and 0.85 for the extrinsic motivation sub-dimension. Cronbach- $\alpha$ reliability coefficient of the whole scale takes the value 0.91 .Considering that Cronbach- $\alpha$ reliability coefficients obtained from both sub-dimensions and all of the scale are well above 0.70 , it can be stated that the scale is reliable.

The scale was confirmed to be two-dimensional with confirmatory factor analysis. The scale consists of 32 items, with 19 items for the intrinsic motivation dimension and 13 items for the extrinsic motivation dimension. In the scale, items 10,12 and 13 are reverse items. All $t$ values for the items were found to be significant. Item factor loads took values between 0.30 and 0.86 . 
When the indexes were examined, the value of 4.53 was found when the chi-square value was divided by the degrees of freedom. This value is less than the cut-off value of 5 and provides evidence of validity. CFI, NNFI and IFI values were calculated as $0.91,0.90$ and 0.91 , respectively. If these values are greater than 0.90 , it means that model data fit is acceptable. When the error indexes of the model are examined, the SRMR and RMSEA value, which gives the model fit for the standardized errors of the model, is calculated as 0.09 , and if this value is less than 0.10 , it is an indication that the model data fit is acceptable.

Cronbach alpha coefficients for the reliability of the scale were calculated as 0.94 for the intrinsic motivation dimension and 0.97 for the extrinsic motivation dimension. Since these values are greater than 0.70 and quite high, it can be stated that the scale is reliable.

Discussion and Conclusion. In previous studies on this subject; Doğan (2009) adapted the "Motivation and Attitude Scale" developed by Gardner (1985) into Turkish. Mehdiyev, Uğurlu, and Usta (2017) worked with students who took English lessons at the Faculty of Education and developed the "Motivation Scale in English Language Learning", which consists of 3 factors. Karcl and Gündoğdu (2018) developed a scale consisting of four factors in their study with university preparatory classes. Unlike other studies, this study is a scale that can be applied to university-level English preparatory classes with two factors, "intrinsic motivation" and "extrinsic motivation". According to CFA results, this scale has a reliability coefficient of 0.94 in the intrinsic motivation dimension, 0.97 in the extrinsic motivation dimension and 4.53 when divided by the chi-square value of the degree of freedom. SRMR and RMSEA value was calculated as 0.09 . It can be seen that a valid and reliable motivation scale for learning English has been developed. With this scale, the motivation levels of students studying English in preparatory classes at different universities can be determined; by this means, programs can be organized to keep students' motivation levels high. 


\section{Giriş}

Günümüzde yabancı dil eğitiminin her geçen gün daha da önem kazandığını görülmekte, yabancı dil öğrenmek için pek çok kişi çokça para ve zaman harcamaktadır. 'Lingua franca' olarak İngilizce öğreniminin çoğu dillerin önüne geçmiş durumda olması sebebiyle kültürel, ekonomik ve teknolojik olarak diğer ülkelerle ilişkilerin sürdürülebilmesini sağlamak için pek çok üniversitede eğitim dili olarak İngilizce kullanılmaktadır. İngilizce öğretiminde kullanılan yöntemler İngilizce'nin yaygınlaşmasında önemli bir rol oynamaktadır (Özdemir, 2006). Ancak öğrencilerin İngilizce öğrenmeye yönelik görüşleri veya yetersizlikleri istenilen düzeye gelmelerini engelleyici bir faktör olabilmektedir. Bu nedenle, öğrencilerin yabancı dil öğrenmeye yönelik motivasyonlarını belirlemek ve buna uygun programlar hazırlamak, dil öğrenme ve öğretme sürecini olumlu yönde etkilemektedir (Dörnyei, Muir ve İbrahim, 2014). Motivasyon düzeyi yüksek bir öğrencinin, daha zeki ama motivasyon düzeyi daha düşük olan bir öğrenciye kıyasla daha başarılı olabileceği öngörülmektedir (Gömleksiz, 2002).

Öğrencilerin dil öğrenmeye yönelik olumsuz yargıları, kendilerini yetersiz buldukları veya kaygı duydukları noktalar olabilir ve bu da öğrencilerin motivasyonlarını etkileyebilir. Buna yönelik olarak, kendi gereksinimlerini önplanda tutan öğrenenler içsel motivasyon, dışarıdan ödül veya cezayla harekete geçen öğrenenler ise dışsal motivasyon araçları ile motive olmaktadır (Mehdiyev, Gonca ve Uğurlu, 2016). Dil öğretiminde istenilen başarıya ulaşabilmek için öğretmenlerin alan bilgisi, dil bilgisi ve kişisel yeterliliklerinin yanısıra öğrenciyi derste motive edebilmesi de oldukça önemlidir (Atay, 2004). Bu sebeple, bu araştırmada yükseköğretim düzeyindeki öğrencilerin de İngilizce öğretiminde başarıyı etkileyen önemli bir etken olduğu düşünülen motivasyon düzeyinin belirlenmesi amacıyla bir ölçme aracının geliştirilmesi hedeflenmiştir. Ölçek maddelerinin oluşturulmasında öz belirleme kuramı temele alınmıştır. Bu kurama göre, insanların tümü temel psikolojik ihtiyaçları açısından aynı özelliklere sahiptir. Dolayısıyla, bu kurama dayalı yapılan bir araştırmadan elde edilen bulgular, bireylerin davranışlarını ve ihtiyaçlarını anlamada yardımcı olabilecektir (Çankaya, 2009).

Çalışmada kullanılan ölçme aracında yer alan maddeleri oluştururken yapılan alan yazın taraması sonucunda bazı çalışmalardan da esinlenilmiştir (Aygün, 2017; Karcı ve Gündoğdu, 2018; Mehdiyev vd., 2017). Aygün (2017), çalışmasında İngilizce öğrenme motivasyonunu azaltan unsurlar hakkındaki görüşler üzerine bir ölçek geliştirmiştir. Bu çalışmada, hazırlık sınıfında eğitim gören öğrencilerin motivasyonlarını olumsuz bir şekilde etkileyen etmenleri araştırmış ve motivasyondaki azalma derecesini ölçen bir ölçek geliştirmiştir. Mehdiyev vd. (2017) hazırlamış olduğu İngilizce dil öğreniminde motivasyon ölçeğinde eğitim fakültesi öğrencileriyle çalışılmış, ölçeğin alt başlıkları 'kişisel kullanım', 'tutum' ve 'özgüven' şeklinde oluşmuştur. Karcı ve Gündoğdu (2018), hazırladıkları İngilizce öğrenmeye yönelik motivasyon ölçeğinde 'beğeni', 'istek', 'kariyer' ve 'yetenek' şeklinde dört faktörlü bir ölçek geliştirmişlerdir. İlgili literatüre bakıldığında kullanıma hazır olan bu ölçekler dışında içsel ve dışsal motivasyon açısından üniversite hazırlık öğrencilerinin İngilizce öğrenmeye yönelik motivasyonlarını ölçen bir ölçeğin eksikliği görülmektedir.

\section{Araştırmanın Amacı}

Bu çalışmanın amacı, üniversite hazırlık sınıfı öğrencilerinin İngilizce öğrenmeye yönelik motivasyonlarını ölçen geçerli ve güvenilir Likert-tipi bir ölçme aracı geliştirmektir.

\section{Yöntem}

Araştırmada, birinci uygulamada İzmir ilinde bulunan Ege Üniversitesi Yabancı Diller Yüksekokulu'nda öğrenim gören tüm İngilizce hazırlık sınıfı öğrencileri, ikinci uygulamada İzmir ilinde bulunan Yaşar Üniversitesi Yabancı Diller Yüksekokulu'nda öğrenim gören tüm İngilizce hazırlık sınıfı 
öğrencileri ile çalışılmıştır. Çalışma için bilimsel araştırmalarda dikkat edilmesi gereken etik ilkeler göz önünde bulundurularak Aydın Adnan Menderes Üniversitesi etik kuruluna başvurulmuş, 84982664050.01.04 sayılı 28.07.2020 tarih ve 2020/11 sayılı Eğitim Araştırmaları Etik Kurulu toplantısında alınan VIII nolu karar ile izin alınmıştır. Bir araştırmada araştırmacı etik olarak, çalışmasında izlediği yolları, nereden başlayıp nereye geldiğini açıklıkla ve dürüstlükle belirtmelidir. Bu nedenle, etiğe uygun bir bilimsel araştırma oldukça uzun bir vakit alır ve daha yüksek bir bütçe ayırmak gerekir (Erdem, 2012). Bu çalışmanın tamamlanması yaklaşık olarak bir yıl sürmüş, alanyazın taramalarının ve daha önce yapılan çalışmaların irdelenmesi sonrasında uygulamalara geçilmiştir. Uygulama öncesinde araştırmanın amacı, önemi, alana sağlayacağı faydalar, verilen cevaplarda dürüstlüğün ve içtenliğin önemi, uygulamanın alacağı süre gibi etik öneme sahip bilgiler öğretim elemanları ve öğrencilere ayrıntılı olarak verilmiş, elde edilen sonuçlar bilgilendirme amaçlı uygulanan kurumlarla paylaşıımıştır.

\section{Örneklem}

Çalışmanın örneklemini, ilk uygulamada Ege Üniversitesi Yabancı Diller Yüksekokulu'nda öğrenim gören 554, ikinci uygulamada ise Yaşar Üniversitesi Yabancı Diller Yüksekokulu'nda öğrenim gören 545 İngilizce hazırlık sınıfı öğrencisi oluşturmuştur. Bu öğrenciler üniversitede kendi bölümlerinin derslerinden önce İngilizce hazırlık eğitimini geçmek zorundadır. Eğitim alırken öğrenciler başlangıç düzeyinden ileri düzeye kadar farklı seviyelerde sınıflandırımakta ve hazırlık programında Ege Üniversitesi'nde haftada 24, Yaşar Üniversitesi'nde haftada 26 ders saati bulunmaktadır. Uygulamalar aynı gün içinde ve aynı ders saatinde öğretim elemanları ve öğrenciler detaylı bilgilendirilerek yapılmıştır. Örneklem, ağırlıklı olarak B1 düzeyi İngilizce öğrenenlerinden oluşmakla birlikte ulaşılabilen tüm öğrencilere uygulama yapıldığı için az sayıda $A 1, A 2, B 2$ ve $C 1$ düzeyinde öğrenenleri de içermektedir.

\section{Ölçme Aracının Geliştirilmesi}

Bu bölümde, yükseköğretim düzeyinde İngilizce hazırlık sınıfı öğrencilerinin İngilizce öğrenmeye yönelik motivasyon düzeylerini ortaya koymak amacıyla tasarlanmış olan bu ölçeğin geliştirilme aşamasında takip edilen basamaklardan söz edilmiştir.

\section{Ölçeğin yapısı}

Bu ölçek, öğrencilerin İngilizce öğrenmeye yönelik motivasyon düzeylerini ortaya koymak için geliştirilmiş Likert tipinde bir ölçektir. Ölçme aracındaki maddelerin cevap seçenekleri, "Kesinlikle Katılıyorum", "Katılıyorum", "Kısmen katılıyorum", "Katılmıyorum" ve "Kesinlikle Katılmıyorum" şeklinde tasarlanmıştır.

\section{Uzman görüşüne göre kapsam geçerliğinin belirlenmesi}

Öncelikle tasarı haline getirilen ölçek, daha sonra konu alanı ve alan eğitim uzmanı olan 9 öğretim elemanına incelenmek üzere sunulmuştur. Uzman görüşü öncesinde içsel motivasyon ve dışsal motivasyon şeklinde 2 boyutlu olup 52 maddeden oluşan ölçek, uzman görüşü sonrasında 53 madde olarak düzenlenmiştir. ifadeler uzmanlar tarafından değerlendirilirken çoğunlukla akıcılık, açıkık, dilin uygun kullanımı, anlaşılırlık ve motivasyon ifadelerinin nasıl yazıldığı gibi kriterler temel alınmıştır. Yapılan öneriler doğrultusunda, dil ve anlaşılırlık açısından düzeltilmesi gerekli görülen ifadeler düzeltilmiştir. 


\section{ilk Uygulamanın Yapılması}

Uzman görüşleri sonucunda tekrar düzenlenen ölçme aracı, yapı geçerliği ve güvenirlik katsayısı değerlerini belirleme amacıyla basit seçkisiz örnekleme yöntemi kullanılarak 554 kişilik öğrenci grubuna uygulanmıştır. Karasar (1995) tarafından, bir ölçek geliştirilirken ön deneme aşaması için en az 50 gerektiği belirtilmiştir. Ölçeğin yapı geçerliğinin incelenmesi amacıyla yapılan açımlayıc faktör analizi sonucu ile maddelerin bazılarının istenildiği gibi çalışmadığı görülmüş ve bu maddelerin ölçülmek istenen özelliği ölçemediği anlaşıldığından ölçekten çıkarılmıştır. Madde çıkarma işlemi sonrasında tekrar AFA yapılarak işlem sonlandırılmış, ölçek 32 maddeyle son halini almıştır.

\section{Ölçeğin Faktör Analizi ve Güvenilirlik Çalışmaları}

Ölçme aracının deneme formu, ön uygulama sonuçlarına ve uzman görüşlerine göre düzenlenmiştir. Ölçme aracının yapı geçerliğinin belirlenmesi, alt boyutlarının oluşturulması ve güvenirlik düzeyinin saptanabilmesi için basit seçkisiz örnekleme yöntemiyle 545 kişilik öğrenci grubuna uygulanmıştır. Yapı geçerliği, özellikle sosyal alanlardaki bilimsel çalışmaların geçerliği için olmayıp bunun yanı sıra, teorik açıdan ilgili ve anlamsız deneysel faktörler arasındaki farklıı̆ın ortaya koyulabilmesi için de kullanılabilmektedir. Bu şekilde, pek çok sorunun cevaplanabilmesi için uygun olan yapı geçerliği kullanılabilir. Böylelikle, yapılan ölçümler için oldukça faydalı katkılar sağlanabilmektedir (Zeller, 1988). Uygulama sonunda toplanan verilerin analizi için SPSS 23.0 paket programından yararlanılmıştır. Yapılan doğrulayıc faktör analizi sonrasında madde çıkarma işlemine gerek kalmaksızın ölçek son halini almıştır.

\section{Bulgular}

İngilizce öğrenmeye yönelik motivasyon ölçeğinin ön uygulamasının geçerlik ve güvenirliğine ilişkin kanitlar

Geliştirilen ölçme aracının yapı geçerliğinin ortaya konulması için açımlayıcı faktör analizi (AFA) yapılmıştır. Bu analizin amacı ölçülmek istenen yapının ne derecede ölçüldüğünün, ölçekte yer alan boyut sayısının ve iyi çalışmayan maddelerin belirlenmesidir. Yapılan ilk analiz sonucunda hiçbir boyuta yer vermeyen maddeler ile beklenen yönde çalışmayan maddeler ölçekten çıkarılmıştır. Her bir madde tek tek çıkarılarak analiz tekrarlanmıştır. Bu yaklaşımda ölçekten çıkarılan maddeler içsel motivasyon alt boyutu için $10,11,13,14,15,16,17,21,22$ numaralı maddeler olmak üzere toplam 9 madde çıkarılmıştır. Dışsal motivasyon alt boyutu için ise 1, 2, 3, 4, 5, 6, 7, 8, 11, 18, 19, 21 numaralı maddeler olmak üzere toplamda 12 madde çıkarılmışır. Ölçeğin son halinde boyutlara ilişkin özdeğerler aşağıda verilmiştir.

Tablo 1.

İngilizce öğrenmeye yönelik motivasyon ölçeği açımlayıcı faktör analizi özdeğerleri

\begin{tabular}{ccc}
\hline & \multicolumn{3}{c}{ Özdeğerler } \\
\cline { 2 - 3 } Bileşen & Toplam & Açıklanan Varyans Yüzdesi \\
\hline 1 & 9.05 & 28.28 \\
2 & 3.73 & 40.01 \\
\hline
\end{tabular}

Ölçeğe ilişkin özdeğerler dikkate alındığında ölçeğin iki alt boyuttan oluştuğu sonraki boyutların özdeğerinin $1^{\prime}$ den küçük olduğu bulunmuştur. Ölçek toplam varyansın \%40'ını açıklamaktadır. Maddelerin alt boyutlara verdikleri faktör yükleri ise Tablo 2'de verilmiştir. 
Tablo 2.

İngilizce öğrenmeye yönelik motivasyon ölçeği açımlayıcı faktör analizi faktör yükleri

\begin{tabular}{|c|c|c|}
\hline Madde & 1. Boyut & 2. Boyut \\
\hline i1 & .781 & \\
\hline $\mathrm{i} 2$ & .606 & \\
\hline ¡3 & .863 & \\
\hline i4 & .659 & \\
\hline i5 & .824 & \\
\hline i6 & .845 & \\
\hline ¡7 & .737 & \\
\hline i8 & .716 & \\
\hline i9 & .724 & \\
\hline ¡12 & .403 & \\
\hline i18 & .811 & \\
\hline ¡19 & .408 & \\
\hline$i 20$ & .464 & \\
\hline i23 & .607 & \\
\hline ¡24 & .540 & \\
\hline $\mathrm{i} 25$ & .596 & \\
\hline i26 & .616 & \\
\hline i27 & .569 & \\
\hline i28 & .521 & \\
\hline d9 & & .425 \\
\hline $\mathrm{d} 10$ & & .364 \\
\hline $\mathrm{d} 12$ & & .608 \\
\hline d13 & & .666 \\
\hline d14 & & .557 \\
\hline d15 & & .552 \\
\hline $\mathrm{d} 16$ & & .587 \\
\hline d17 & & .643 \\
\hline$d 20$ & & .635 \\
\hline$d 22$ & & .314 \\
\hline$d 23$ & & .392 \\
\hline$d 24$ & & .382 \\
\hline $\mathrm{d} 25$ & & .407 \\
\hline
\end{tabular}

Tablolar incelendiğinde içsel motivasyon maddelerinin tamamı 1. Faktöre, dışsal motivasyon tamamı ise 2. Faktöre yük vermiştir. Bu nedenle 1. Faktör İçsel Motivasyon Alt Boyutu, 2. Faktör ise Dışsal Motivasyon Alt Boyutu olarak isimlendirilmiştir.

Ölçeğin güvenirliğine ilişkin yapılan analizler sonucunda her bir maddenin ait olduğu alt boyut ile korelasyonları incelenmiştir. Tablo 3 incelendiğinde maddelerin tümünün ait oldukları alt boyutlarla kabul edilebilir korelasyonları vardır. Ölçeğin alt boyutlarına ilişkin Cronbach- $\alpha$ güvenirlik katsayıları içsel motivasyon alt boyutu için 0.93 , dışsal motivasyon alt boyutu için 0.85 şeklinde hesaplanmıştır. Ölçeğin tümüne ait Cronbach- $\alpha$ güvenirlik katsayısı ise 0.91 değerini almaktadır. 
Bir ölçme aracının güvenirlik katsayısının 0.70 değerinin üstünde olması ölçeğin güvenirliğine ilişkin kanıt oluşturmaktadır (Nunnally, 1978). Ölçeğin hem alt boyutlarından hem de tümünden elde edilen Cronbach- $\alpha$ güvenirlik katsayılarının 0.70 değerinin oldukça üzerinde olduğu dikkate alındığında ölçeğin güvenilir olduğu ifade edilebilir.

Tablo 3.

İngilizce öğrenmeye yönelik motivasyon ölçeği alt boyutlarına ilişkin korelasyon ve güvenirlik değerleri

\begin{tabular}{|c|c|c|c|}
\hline Boyut & Madde & Madde Test Korelasyonu & Alpha \\
\hline \multirow[b]{3}{*}{ İçsel } & i1 & .743 & \multirow{14}{*}{0.93} \\
\hline & i2 & .575 & \\
\hline & i3 & .827 & \\
\hline \multirow{11}{*}{ Motivasyon } & ¡4 & .632 & \\
\hline & i5 & .780 & \\
\hline & i6 & .806 & \\
\hline & ¡7 & .704 & \\
\hline & i8 & .697 & \\
\hline & ¡9 & .709 & \\
\hline & ¡12 & .390 & \\
\hline & ¡18 & .780 & \\
\hline & ¡19 & .393 & \\
\hline & $\mathrm{i} 20$ & .441 & \\
\hline & $\mathrm{i} 23$ & .599 & \\
\hline \multirow{3}{*}{ Dışsal } & d9 & .425 & \multirow{13}{*}{0.85} \\
\hline & $\mathrm{d} 10$ & .364 & \\
\hline & $\mathrm{d} 12$ & .608 & \\
\hline \multirow{10}{*}{ Motivasyon } & d13 & .666 & \\
\hline & d14 & .557 & \\
\hline & d15 & .552 & \\
\hline & d16 & .587 & \\
\hline & d17 & .643 & \\
\hline & $\mathrm{d} 20$ & .635 & \\
\hline & $\mathrm{d} 22$ & .294 & \\
\hline & $\mathrm{d} 23$ & .392 & \\
\hline & $\mathrm{d} 24$ & .380 & \\
\hline & $d 25$ & .382 & \\
\hline
\end{tabular}

\section{İngilizce öğrenmeye yönelik motivasyon ölçeğinin geçerlik ve güvenirliğine ilişkin kanıtlar}

Ölçeğin geçerliği için yapılan final uygulamasında 545 bireyden veri toplanmıştır. Doğrulayıcı faktör analizi ile ölçeğin iki boyutlu olduğu doğrulanmıştır. Bu boyutlar içsel motivasyon ve dışsal motivasyon olarak ayrılmaktadır. İçsel motivasyon boyutu 19 madde, dışsal motivasyon boyutu 13 madde olmak üzere ölçek toplam 32 maddeden oluşmaktadır. Ölçekte 10, 12. ve 13. Madde ters maddelerdir. Maddelere ilişkin tüm t değerleri anlamlı bulunmuştur. Madde faktör yükleri ise 0.30 ile 0.86 arasında değerler almıştır. Faktör yükleri Şekil 1'de verilmiştir. 


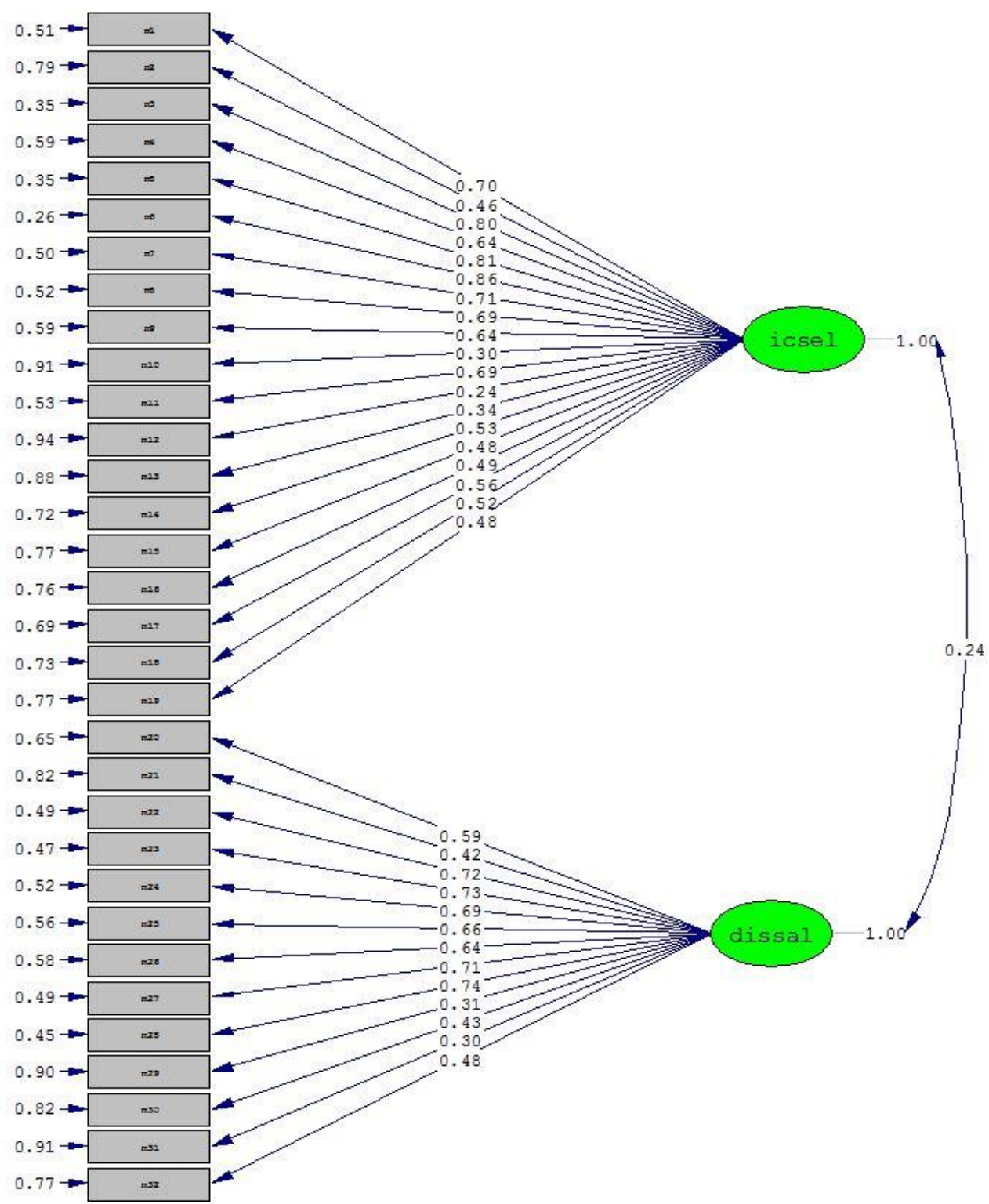

Şekil 1. İngilizce öğrenmeye yönelik motivasyon ölçeği standartlaştırılmış faktör yükleri

Ölçeğin doğrulayıcı faktör analizi sonuçlarının uyum istatistikleri Tablo 4'de verilmiştir.

Tablo 4.

İngilizce yazmaya yönelik tutum ölçeği uyum iyiliği testlerine ilişkin değerler

\begin{tabular}{cccccccccc}
\hline Ki-kare & Df & CFI & NNFI & GFI & AGFI & IFI & SRMR & RMSEA & \%90 C.I. RMSEA \\
\hline 2094.04 & 462 & 0.91 & 0.90 & 0.78 & 0.76 & 0.91 & 0.090 & 0.090 & $0.089 ; 0.090$ \\
\hline
\end{tabular}

Tablo 4incelendiğinde, ölçekle ilgili kurulan yapısal modelin doğrulayıcı faktör analizi ile görülen uyum indeksleri, model ve veri arasında kabul edilebilir seviyede uyum olduğunu ortaya koymaktadır. Bu indekslere bakıldığında ki kare değeri serbestlik derecesine bölününce 4.53 değeri bulunmuştur. Bu değer kesme noktası olan 5 değerinden küçüktür ve geçerliğe ilişkin kanıt oluşturmaktadır. CFI, NNFI ve IFI değerleri sırasıyla $0.91,0.90$ ve 0.91 olarak hesaplanmıştır. Bu değerlerin 0.90 değerinden büyük olması model veri uyumunun kabul edilebilir olduğunu ifade etmektedir. Modelin hata indeksleri tetkik edildiğinde standartlaştırılmış hatalarına ilişkin model uyumu veren SRMR ve RMSEA değerinin 0.09 olarak hesaplandığı ve bu değerin $0.10^{\prime}$ dan küçük olması model veri uyumunun kabul edilebilir düzeyde 
olduğunun göstergesidir.

Ölçeğin güvenirliğine ilişkin Cronbach alfa katsayıları, içsel motivasyon boyutu için 0.94, dışsal motivasyon boyutu için ise 0.97 olarak hesaplanmıştır. Bu değerler 0.70 değerinden büyük ve oldukça yüksek olduğundan ölçeğin güvenilir olduğu ifade edilebilir.

\section{Tartışma, Sonuç ve Öneriler}

Günümüzde en az bir yabancı dil biliyor olma gerekliliği pek çok alanda hissedilmektedir. Özellikle iletişim dili olarak yoğun kullanıma sahip olan İngilizce'yi öğrenmek, yetişmekte olan neslin önceliklerindendir. Yabancı dil öğrenme isteği ve düzeyi de öğrenenlerin gördüğü eğitimin başarısını etkileyen en önemli faktörlerden biridir. Öğrenenlerin İngilizce öğrenmeye yönelik motivasyonlarının düzeyi, İngilizce öğrenme hedeflerine ulaşmada ne derece başarılı olacaklarını da etkileyecektir. Bu nedenle, öğrenenlerin İngilizce öğrenme düzeylerini etkileyen motivasyon faktörü ile ilgili bir ölçek geliştirilmesi ihtiyacı görülmüştür. Daha önce bu konuda yapılan çalışmalarda son zamanlarda artış olduğu görülmekte ve farklı yaşlardaki/düzeylerdeki öğrenciler için farklı ölçekler geliştirildiği/uyarlandığı görülmektedir. Doğan (2009), Gardner'ın (1985) geliştirmiş olduğu 'Motivasyon ve Tutum Ölçeği'ni Türkçe'ye uyarlamış; çalışmasında uygulamayı Eskişehir Osmangazi Üniversitesi hazırlık sınıfı öğrencileriyle yürütmüştür. Yılmaz (2013), İngilizce öğrenmeye yönelik motivasyon düzeylerini belirlemek için lise öğrencileriyle çalışmıştır. Doğan (2009) tarafından uyarlanan motivasyon ölçeğini Karakış (2014) lise öğrencilerinin motivasyonlarını belirlemek amacıyla doktora tezinde kullanmış, ölçeğin uyum indekslerini inceleyerek kabul edilebilir düzeyde olduğunu belirtmiştir. Ataman (2017) yürüttüğü tez çalışmasında Doğan (2009) tarafından uyarlanan ölçekten yararlanmış, örneklem olarak Düzce Üniversitesi hazırlık sınıfı öğrencileriyle çalışmıştır. Mehdiyev vd. (2017) İngilizce dersini Eğitim Fakültesi'nde alan öğrencilerle çalışarak 3 faktörden oluşan İngilizce Dil Öğreniminde Motivasyon Ölçeği'ni geliştirmişlerdir. Karcı ve Gündoğdu (2018) Dokuz Eylül Üniversitesi ve Muğla Sıtkı Koçman Üniversitesi hazırlık sınıfı öğrencileriyle yaptıkları çalışmada dört faktörden oluşan bir ölçek geliştirmişlerdir. Yapılan çalışmalar değerlendirildiğinde, bu çalışma, diğer bazı çalışmalarla üniversite hazırlık öğrencileriyle çalışılması açısından benzerlik gösterirken farklı olarak 'içsel motivasyon' ve 'dışsal motivasyon' şeklinde iki faktöre sahiptir. Bu ölçek, üniversite düzeyinde İngilizce hazırlık sınıflarına uygulanabilecek bir ölçek olmakla beraber, gerekli çalışmalar yapıldığı takdirde üniversitede herhangi bir sınıfta İngilizce dersi alan öğrencilere ve/veya İngilizce öğrenen yetişkinlere, İngilizce öğrenim gören lise öğrencilerine de uygulanabilir.

Ölçeğin uygulama sonuçlarından elde edilen sonuçlara göre; kişisel bilgilerle ilgili yeterli miktarda veri elde edilememesi sebebiyle öğrencilerin bölümleri, yaşları, cinsiyetleri, ebeveynlerinin eğitim düzeyi, ailelerinin ortalama geliri, hazırlık eğitimini tekrar ediyor olup olmayışları ve hazırlık muafiyet notları analize dahil edilememiştir.

Ingilizce öğrenmeye yönelik motivasyon ölçeği geliştirme sürecinin doğrulayıcı faktör analizi sonucunda; üniversite öğrencilerinin İngilizce öğrenmeye yönelik motivasyonlarının iki boyutlu bir yapı ile içsel motivasyon boyutunda 0.94 , dışsal motivasyon boyutunda ise 0.97 güvenilirlik katsayısına ve ki kare değeri serbestlik derecesine bölündüğünde 4.53 değerine sahiptir. Doğrulayıcı faktör analiziyle ölçeğin 'içsel motivasyon' ve 'dışsal motivasyon' şeklinde iki boyuta sahip olduğu doğrulanmıştır. Uyum indeks değerlerine bakıldığında CFI, NNFI ve IFI değerleri sırasıyla $0.91,0.90$ ve 0.91 olarak, SRMR ve RMSEA değeri 0.09 olarak hesaplanmıştır. İçsel motivasyon boyutunda 19, dışsal motivasyon boyutunda 13 maddeyle ölçek toplam 32 maddeyle son halini almıştır. Analiz sonuçları incelendiğinde, İngilizce öğrenmeye yönelik geçerli ve güvenilir bir motivasyon ölçeği geliştirildiği görülmektedir. Geliştirilen bu ölçekle farklı üniversitelerde hazırlık sınıflarında İngilizce öğrenim gören öğrencilerin motivasyonlar düzeyleri belirlenebilir ve böylelikle öğrencilerin motivasyon düzeylerini yüksek tutacak 
programlar düzenlenebilir. Ayrıca, bu ölçek, gerekli güvenirlik çalışmaları yapıldığı takdirde, yabancı dil ağırlıklı eğitim gören lise son sınıf düzeyindeki öğrencilerle de çalışılarak farklı düzeylerde kullanılabilecek şekilde geliştirilebilir. 


\section{Kaynakça}

Atay, D. (2004). İngilizce öğretmenlerinin motivasyon stratejileri. Hasan Ali Yücel Eğitim Fakültesi Dergisi, 1, 99108.

Aygün,Ö. (2017). Hazırlık sınıfında okuyan Türk öğrencilerin Ingilizce öğrenme motivasyonlarını azaltan unsurlar ölçeği. (Yayımlanmamış yüksek lisans tezi). Anadolu Üniversitesi, Eğitim Bilimleri Enstitüsü, Eskişehir

Ataman, O. (2017). Üniversite hazırlık sınıfı öğrencilerinin Ingilizce öğrenmeye yönelik motivasyon düzeyleri ve tutumları ile hazırlık sınıfı başarı puanları arasındaki ilişki. (Yayımlanmamış yüksek lisans tezi). Sakarya Üniversitesi, Eğitim Bilimleri Enstitüsü, Sakarya.

Çankaya, Z. C. (2019). Özerklik desteği, temel psikolojik ihtiyaçların doyumu ve öznel iyi olma: Öz-belirleme kuramı. Türk Psikolojik Danışma ve Rehberlik Dergisi,4(31), 23-31.

Doğan, Ö. (2009). Ingilizce hazırlık okuyan öğrencilerin motivasyon düzeyleri. (Yayımlanmamış Yüksek lisans tezi). Eskişehir Osmangazi Üniversitesi, Sosyal Bilimler Enstitüsü.

Dörnyei, Z., Muir, C. ve Ibrahim, Z. (2014). Directed motivational currents: Energising languages learning by creating intense motivational pathways. Motivation and foreign language learning: From theory to practice, 9-30.

Erdem, A. R. (2012). Bilim insanı yetiştirmede etik eğitimi. Journal of Higher Education \& Science/Yükseköğretim ve Bilim Dergisi, 2(1), 25-32.

Gömleksiz, M. N. (2002). Üniversitelerde yürütülen yabancı dil derslerine ilişkin öğrenci görüşlerinin değerlendirilmesi. Fırat Üniversitesi Sosyal Bilimler Dergisi, 12(1), 143-158.

Karakış, Ö. (2014). Lise öğrencilerinin ingilizce dersine yönelik kaygıları, motivasyonları, öz-yeterlik algıları ve ingilizce ders başarıları arasındaki ilişki. (Yayımlanmamış doktora tezi). Abant ̇̇zzet Baysal Üniversitesi, Eğitim Bilimleri Enstitüsü, Bolu.

Karasar, N. (1995). Bilimsel araştırma yöntemi: Kavramlar, ilkeler ve teknikler. Ankara: 3A Araştırma Eğitim Danışmanlık Ltd. Şti.

Karcı, C., ve Gündoğdu, K. (2018). İngilizce öğrenmeye yönelik motivasyon ölçeği: geçerlik ve güvenirlik çalışması. International Journal of Languages' Education and Teaching, 6(1), 103-116.

Mehdiyev, E., Usta, G. ve Uğurlu, C. T. (2016). İngilizce dil öğreniminde motivasyon. Elektronik Sosyal Bilimler Dergisi, 15(57). doi: https://doi.org/10.17755/esosder.58834

Mehdiyev, E., Uğurlu, C. T. ve Usta, H. G. (2017). İngilizce Dil Öğreniminde Güçlükler Ölçeği geçerlik ve güvenirlik çalışması. Eğitimde Kuram ve Uygulama, 13(3), 411-429.

Özdemir, E. A. (2006). Türkiye'de İngilizce öğreniminin yaygınlaşmasının nedenleri. Mersin Üniversitesi Eğitim Fakültesi Dergisi, 2(1), 28-35. Erişim adresi:

https://dergipark.org.tr/tr/pub/mersinefd/issue/17390/181751

Yılmaz, E. (2013). Lise öğrencilerinin İngilizce dersi motivasyon düzeylerinin ve motivasyon tiplerinin belirlenmesi. Karaelmas Journal of Educational Sciences, 1, 1-10.

Zeller, R. A. (1988). Validity. J. P. Keeves (Ed.) Education research, methodology, and measurement an international handbook (s. 322-330) içinde. Oxford: Pergamon Press PLC, Headington Hill Hall. 